\title{
RESPONSE OF LANTANA CAMARA PLANTS TO FOLIAR APPLIED CITRIC ACID FOR DECREASING THE HARMFUL EFFECT OF HEAVY METALS POLLUTION IN THE IRRIGATION WATER (C) EFFECT OF LEAD
}

\author{
N.A. El-Shanhorey ${ }^{*}$ and O.N. Emam** \\ * Botanical Gardens Research Department, Horticultural Research Institute, ARC, Alexandria, Egypt \\ ** Horticultural Department, Faculty of Agriculture, Beni-Suif University, Egypt
}

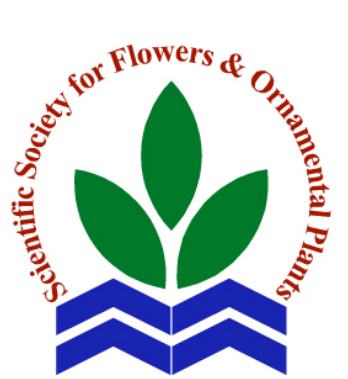

Scientific J. Flowers \& Ornamental Plants, 7(2):93-107 (2020).

Received: 8/4/2020

Accepted: $3 / 5 / 2020$

ABSTRACT: The present study was carried-out at Antoniadis Research Branch, Horticultural Research Institute, Agriculture Research Center (ARC), Alexandria, Egypt during two successive seasons of 2018 and 2019. The aim of this study was to evaluate the effects of irrigation water contaminated with lead on the growth of Lantana camara plants and the possibility of using citric acid spray treatments to overcome the effects of lead pollution. Seedlings of Lantana camara were planted individually in plastic pots $(20 \mathrm{~cm}$ diameter) filled with $5 \mathrm{~kg}$ of sandy soil. The lead contaminated irrigation water treatments were 0,100, 200 and $300 \mathrm{mg} / \mathrm{l}$. The plants were also monthly sprayed by citric acid at concentrations of 0,250 and $500 \mathrm{mg} / \mathrm{l}$. The results showed that for vegetative growth parameters there were no significant difference in the interaction between lead concentrations in water of irrigation and foliar spray by citric acid, while significant reductions were observed in all parameters after irrigation with lead contaminated water. However, significant increases in vegetative growth parameters were observed after 500 $\mathrm{mg} / \mathrm{l}$ citric acid application. For chlorophyll and carbohydrate contents, the highest significant value was obtained in plants irrigated with tap water and sprayed with $250 \mathrm{mg} / \mathrm{l}$ citric acid while the highest significant level of lead content in leaves, stem and roots was obtained due treatment by $300 \mathrm{mg} / \mathrm{l}$ lead without application of citric acid.

Key words: Lantana camara, polluted irrigation water, lead, citric acid.

\section{INTRODUCTION}

Phytoremediation has become an effective and affordable technological solution used to extract or remove toxic metals from polluted soil. Phytoremediation is the use of plants to clean polluted soils, sediments and water. This technology is environment friendly and potentially cost effective. Plants with exceptional metalaccumulating capacity are known as hyperaccumulators (Choruk et al., 2006). Plants need trace amounts of heavy metals but their excessive availability may cause plant toxicity (Sharma et al., 2006).
Phytotoxic concentration of heavy metals referred in the literature does not always specify the levels (Wua et al., 2010).

Lead is a toxic heavy metal that has an environmental concern (Mahler et al., 1981). There are many sources of environmental lead pollution, including fuel combustion, industrial sludges, phosphate fertilizers, and mine tailings (Unhalekhana and Kositanont, 2008).

Lead is one of the main sources of environmental pollution. Many studies have shown that lead inhibits metabolic processes in the plants such as nitrogen assimilation, 
photosynthesis, respiration, water uptake, and transcription (Kurepa et al., 1997 and Boussama et al., 1999). Lead may inactivates various enzymes by binding to their SH-groups (Rauser, 1995), and can intensify the processes of reactive oxygen species (ROS) production leading to oxidative stress (Cuypers et al., 1999; Prasad et al., 1999). In addition, lead can negatively affect mitochondria structure by decreasing number of mitochondrial cristae, which in turn can lower the capability of oxidative phosphorylation (Malecka et al., 2001).

Endogenous organic acids are the source of both carbon skeleton and energy for cells and are used in the respiratory cycle and other biochemical pathways (Da Silva, 2003). Citric acid (CA) is an organic acid mainly served as antioxidant and involved in plant metabolism through its role in Krebs cycle during the respiration in mitochondria which produces cellular energy by oxidative phosphorylation (Taize and Zaiger, 2002). This energy is required for different physiological processes and development of the mechanisms of resistance systems under different stressful factors. It is created by addition of acetyl-CoA to oxaloacetic acid that is converted to succinate and malate in next steps (Wills et al., 1981).

Lantana camara L., which is a new plant owing to its remarkable capacity to extract lead and cadmium from polluted soils in Vietnam (Huynh, 2009) has been suggested as a model species for research on phytoextraction of metals. Moreover, this plant has a rapid growth and developing very fast. It can also grow in extreme conditions and is able to endure long periods of drought or heavy rains. Finally, its multicolored flowers allow integration into a floral arrangement of a landscaping project (Huynh, 2009).

In this study Lantana camara was selected due to its characteristics as nonedible plant which can grow in tropical areas and it has many uses in landscaping. Therefore, the objective of this study was to determine the potential of Lantana camara in removing lead from soil affected by lead polluted irrigation water and to investigate it is ability for removing heavy metals.

\section{MATERIALS AND METHODS}

The present study was carried-out at Antoniades Research Branch, Horticultural Research Institute, Agriculture Research Center (ARC), Alexandria, Egypt during two successive seasons of 2018 and 2019.

On 15 $5^{\text {th }}$ of February, 2018 and 2019 in the first and second seasons, respectively, uniform transplants of Lantana camara (15$20 \mathrm{~cm}$ height and 10-15 leaves per plant) were planted individually in plastic pots (20 $\mathrm{cm}$ diameter) filled with $5 \mathrm{~kg}$ sandy soil. The chemical characteristics of the soil were measured as described by Jackson (1958) and presented in Table (1).

On $1^{\text {st }}$ of March (in both seasons), the polluted of irrigation water were initiated. Four concentrations of lead (II) acetate $(\mathrm{Pb}$ $\left.\left(\mathrm{CH}_{3} \mathrm{COO}\right)_{2}\right): 0,100,200$ and $300 \mathrm{mg} / \mathrm{l}$ were prepared and dissolved in the irrigation water. The plants were irrigated three times per week. At the end of the experiment every pot had received about 127 liters of lead polluted water (Table, 2). In both seasons, the plants were monthly sprayed by citric acid from $15^{\text {th }}$ May till $15^{\text {th }}$ August in both seasons at concentrations of 0,250 and 500 $\mathrm{mg} / \mathrm{l}$. The control plants were sprayed with tap water. On $30^{\text {th }}$ of September in the both seasons, the plants were harvested.

In the two seasons, the plants received $\mathrm{N}, \mathrm{P}$ and $\mathrm{K}$ chemical fertilizers in the form of soluble fertilizer (Kristalon 19-19-19) at rate of $1.5 \mathrm{~g}$ /pot. Fertilization was repeated every 30 days throughout the growing season (from $1^{\text {st }}$ of March till $30^{\text {th }}$ of September). In addition, weeds were removed manually upon emergence.

\section{Data recorded:}

\section{Vegetative growth parameters:}

Plant height $(\mathrm{cm})$, number of leaves per plant, leaves dry weight per plant (g), leaves area $\left(\mathrm{cm}^{2}\right)$ according to Koller (1972), branch number per plant, stem diameter 
Table 1. The chemical properties of the used sandy soil for the two seasons 2018 and 2019.

\begin{tabular}{|c|c|c|c|c|c|c|c|c|c|}
\hline \multirow{2}{*}{ Season } & \multirow{2}{*}{ pH } & \multirow{2}{*}{$\begin{array}{l}\text { EC } \\
\mathbf{d S} / \mathbf{m}\end{array}$} & \multicolumn{4}{|c|}{$\begin{array}{c}\text { Water soluble cations } \\
\text { (meq/l) }\end{array}$} & \multicolumn{3}{|c|}{$\begin{array}{c}\text { Water soluble anions } \\
\text { (meq/l) }\end{array}$} \\
\hline & & & $\mathrm{Ca}^{++}$ & $\mathbf{M g}^{++}$ & $\mathrm{Na}^{+}$ & $\mathbf{K}^{+}$ & $\mathrm{HCO}_{3}{ }^{-}$ & $\mathrm{Cl}^{-}$ & $\mathrm{SO}_{4}^{--}$ \\
\hline 2018 & 7.93 & 1.55 & 3.4 & 3.4 & 6.5 & 1.3 & 3.6 & 6.7 & 2.4 \\
\hline 2019 & 7.91 & 1.52 & 3.2 & 3.0 & 6.3 & 1.2 & 3.3 & 6.5 & 2.2 \\
\hline
\end{tabular}

Table 2. Total amount of used irrigation water for each plant (1/pot) in each treatment during the two growing seasons of 2018 and 2019.

\begin{tabular}{|c|c|c|c|c|c|c|c|c|}
\hline \multirow{2}{*}{$\begin{array}{c}\text { Field } \\
\text { Capacity } \\
(\%)\end{array}$} & \multicolumn{8}{|c|}{ Months of first and second seasons } \\
\hline & March & April & May & June & July & August & September & Total \\
\hline $100 \%$ & 14.00 & 15.00 & 16.00 & 17.00 & 20.00 & 23.00 & 22.00 & 127.00 \\
\hline
\end{tabular}

(cm), stem dry weight (g), root length $(\mathrm{cm})$, root dry weight (g), flower number per plant and flower dry weight (g) were also measured.

\section{Chemical analysis:}

- Total chlorophyll index was measured as a SPAD for the fresh middle leaves of plants, for the different treatments under the experiment at the end of the season using Minolta (chlorophyll meter) SPAD 502 according to Yadava (1986).

- Total carbohydrate percentage in the leaves was determined according to Dubios et al. (1956).

- Proline content $(\mathrm{mg} / \mathrm{g})$ in the leaves was determined according to Bates et al. (1973).

- Determination of lead content in Plant samples was determined as follows: Plant samples were divided into leaves, stem and roots, oven dried at $70{ }^{\circ} \mathrm{C}$ for $72 \mathrm{hrs}$ in an oven. The dried plant samples were ground to a powder. The oven dried samples were digested for extraction of lead, using the method described by Piper (1947) and the concentration of heavy metal was assured using an atomic absorption spectrophotometer.

- Available lead in the soil sample was extracted by DPTA-Solution according to Lindsay and Norvell (1978) and measured by Inductively Coupled Plasma Spectrometry.

- Transfer factor (TF) is calculated the ratio between the concentration of metal in the shoots to the concentration of metal in the soil (Chen et al., 2004) as indicates to the efficiency of any plant to transfer any metal from soil to the aerial parts.

The pot experimental design was split plot with three replicates. Each replicate contained three plants. The main plot was lead concentration, while the subplot was citric acid treatments. The obtained data were subjected to analysis of variance (ANOVA) using the SAS program, SAS Institute (SAS Institute, 2002). Means of the individual factors and their interactions were compared by L.S.D test at 5\% level of probability according to Snedecor and Cochran (1989).

\section{RESULTS}

\section{Vegetative growth:}

a. Leaves parameters:

Data presented in Table (3) showed that, in both seasons, irrigation water polluted with lead decreased the tested leaves parameters of Lantana camara plants. While plants irrigated with tap water (control) had the highest mean values of number of leaves per plant (100.50 and 101.66), leaves dry weight (2.05 and $2.41 \mathrm{~g}$ ) and leaves area 
Table 3. Means of number of leaves per plant, leaves dry weight (g) and leaves area $\left(\mathrm{cm}^{2}\right)$ of Lantana camara plants as influenced by lead (Pb), citric acid (CA) and their combinations $(\mathrm{Pb} \times \mathrm{CA})$ in the two seasons of 2018 and 2019.

\begin{tabular}{|c|c|c|c|c|c|c|c|}
\hline \multicolumn{2}{|c|}{ Treatments } & \multicolumn{2}{|c|}{$\begin{array}{l}\text { Number of leaves } \\
\text { per plant }\end{array}$} & \multicolumn{2}{|c|}{$\begin{array}{l}\text { Leaves dry weight } \\
\text { (g) }\end{array}$} & \multicolumn{2}{|c|}{$\begin{array}{l}\text { Leaves area } \\
\qquad\left(\mathrm{cm}^{2}\right)\end{array}$} \\
\hline $\begin{array}{c}\mathbf{P b} \\
(\mathbf{m g} / \mathbf{l})\end{array}$ & $\begin{array}{c}\text { CA } \\
(\mathrm{mg} / \mathrm{l})\end{array}$ & 2018 & 2019 & 2018 & 2019 & 2018 & 2019 \\
\hline \multirow{3}{*}{$\mathbf{0}$} & 0 & 98.50 & 100.33 & 2.01 & 2.36 & 370.44 & 261.95 \\
\hline & 250 & 100.50 & 101.66 & 2.05 & 2.40 & 496.36 & 282.53 \\
\hline & 500 & 102.50 & 103.00 & 2.11 & 2.47 & 401.09 & 287.42 \\
\hline \multirow[t]{2}{*}{ Mean (Pb) } & & 100.50 & 101.66 & 2.05 & 2.41 & 422.63 & 277.30 \\
\hline & 0 & 95.50 & 97.33 & 1.96 & 2.31 & 342.22 & 216.70 \\
\hline \multirow{2}{*}{100} & 250 & 96.50 & 98.33 & 1.98 & 2.35 & 360.02 & 246.52 \\
\hline & 500 & 100.50 & 101.66 & 2.06 & 2.40 & 360.33 & 266.42 \\
\hline \multirow[t]{2}{*}{ Mean (Pb) } & & 97.50 & 99.10 & 2.00 & 2.35 & 354.19 & 243.21 \\
\hline & 0 & 91.00 & 92.83 & 1.87 & 2.25 & 311.81 & 236.11 \\
\hline \multirow[t]{2}{*}{200} & 250 & 93.83 & 94.83 & 1.91 & 2.26 & 317.24 & 241.95 \\
\hline & 500 & 94.83 & 96.66 & 1.94 & 2.29 & 319.23 & 246.56 \\
\hline \multirow{2}{*}{ Mean (Pb) } & & 93.22 & 94.77 & 1.90 & 2.26 & 316.09 & 241.54 \\
\hline & 0 & 88.50 & 90.33 & 1.82 & 2.16 & 219.55 & 191.02 \\
\hline \multirow[t]{2}{*}{300} & 250 & 90.00 & 91.83 & 1.84 & 2.20 & 233.67 & 199.43 \\
\hline & 500 & 91.16 & 92.66 & 1.87 & 2.24 & 274.81 & 215.54 \\
\hline \multirow[t]{2}{*}{ Mean (Pb) } & & 89.88 & 91.60 & 1.84 & 2.20 & 242.67 & 201.99 \\
\hline & 0 & 93.37 & 95.20 & 1.91 & 2.27 & 311.00 & 226.44 \\
\hline \multirow{3}{*}{ Mean (CA) } & 250 & 95.20 & 96.66 & 1.94 & 2.30 & 351.82 & 242.60 \\
\hline & 500 & 97.24 & 98.49 & 1.99 & 2.35 & 338.86 & 253.98 \\
\hline & $\mathbf{P b}$ & 1.68 & 1.56 & 0.03 & 0.03 & 49.37 & 26.34 \\
\hline \multirow{2}{*}{ L.S.D. at 0.05} & CA & 1.95 & 1.81 & 0.04 & 0.04 & 26.80 & 15.79 \\
\hline & $\mathbf{P b} \times \mathbf{C A}$ & 2.25 & 2.09 & 0.04 & 0.04 & 30.80 & 18.15 \\
\hline
\end{tabular}

(422.63 and $277.30 \mathrm{~cm}^{2}$ ) in the first and second seasons, respectively. Increasing the lead concentration significantly reduced in the tested leaves parameters. The highest lead concentration (300 mg/l) significantly produced the lowest mean values of plant number of leaves per plant (89.88 and $91.60)$, leaves dry weight (1.84 and $2.20 \mathrm{~g}$ ) and leaves area (242.67 and $\left.201.99 \mathrm{~cm}^{2}\right)$ in the first and second seasons, respectively, compared with the other concentrations.

Leaves parameters were also significantly affected by spraying the plants with citric acid. In both seasons, the tested leaves parameters were gradually increased when the citric acid concentration was increased from $0 \mathrm{mg} / \mathrm{l}$ (control) to $500 \mathrm{mg} / \mathrm{l}$. Accordingly, data presented in Table (3) showed that Lantana camara plants sprayed with $500 \mathrm{mg} / \mathrm{l}$ citric acid gave significantly higher mean values of number of leaves per plant (97.24 and 98.49), leaves dry weight (1.99 and $2.35 \mathrm{~g}$ ) and leaves area (338.86 and $253.98 \mathrm{~cm}^{2}$ ) in the first and second seasons, respectively, compared with the other concentrations.

Regarding the interaction between irrigation with lead polluted water and citric acid treatments on the tested leaves parameter of Lantana camara plants, the recorded results in the two seasons showed that, the highest values were obtained for plants irrigated with tap water (control) and sprayed with citric acid at $500 \mathrm{mg} / \mathrm{l}$ with mean values of number of leaves per plant (102.50 and 103.00) and leaves dry weight ( 2.11 and $2.47 \mathrm{~g}$ ) in the first and second seasons, while irrigated plants with tap water (control) and sprayed with citric acid at 250 $\mathrm{mg} / \mathrm{l}$ gave mean values of leaves area $\left(496.36 \mathrm{~cm}^{2}\right)$ in the first season while these irrigated with tap water (control) and sprayed with citric acid at $500 \mathrm{mg} / \mathrm{l}$ recorded mean values of leaves area $\left(287.42 \mathrm{~cm}^{2}\right)$ in the second season, respectively, compared with the other concentrations. On the other hand, 
the lowest values of number of leaves per plant (88.50 and 90.33), leaves dry weight (1.82 and $2.16 \mathrm{~g})$ and leaves area (219.55 and $191.02 \mathrm{~cm}^{2}$ ) in the first and second seasons, respectively, were resulted when the plants were irrigated using the highest lead concentration (300 $\mathrm{mg} / \mathrm{l})$ and sprayed with citric acid at $0 \mathrm{mg} / \mathrm{l}$. It is also shown that in many cases, spraying plants with citric acid reduced the adverse effect of polluted water with lead (Table, 3).

\section{b. Stem parameters:}

Data presented in Table (4) showed that irrigation with lead polluted water decreased stem parameter, compared to that of plants irrigated with tap water (control). In both seasons, plants irrigated with tap water had the thickest stem, with mean plant height (34.69 and $40.19 \mathrm{~cm}$ ), number of branch per plant (7.33 and 12.33), stem diameter (0.54 and $0.71 \mathrm{~cm})$ and stem dry weight $(3.13$ and
$4.75 \mathrm{~g}$ ) in the first and second seasons, respectively. Increasing the lead concentration in irrigation water caused a steady reduction in stem parameters. This reduction in stem parameter was significant compared to the control, even at the highest lead concentration (300 mg/l), which gave plant height (30.60 and $36.66 \mathrm{~cm}$ ), number of branch per plant (6.10 and 9.49), stem diameter $(0.40$ and $0.60 \mathrm{~cm})$, and stem dry weight (2.45 and $3.94 \mathrm{~g})$ in the first and second seasons, respectively, compared with the other concentrations.

In contrast to the effect of lead treatments, citric acid treatments improved stem parameters of Lantana camara plants, compared to the control. Moreover, plants sprayed with $500 \mathrm{mg} / \mathrm{l}$ citric acid had significantly mean plant height (33.31 and $39.16 \mathrm{~cm})$, number of branch per plant $(7.04$ and 11.24), stem diameter (0.51 and 0.68 $\mathrm{cm})$ and stem dry weight (2.90 and $4.55 \mathrm{~g})$

Table 4. Means of plant height $(\mathrm{cm})$, branch number per plant, stem diameter $(\mathrm{cm})$ and stem dry weight (g) of Lantana camara plants as influenced by lead $(\mathrm{Pb})$, citric acid (CA) and their combinations (Pb $\times$ CA) in the two seasons of 2018 and 2019.

\begin{tabular}{|c|c|c|c|c|c|c|c|c|c|}
\hline \multicolumn{2}{|c|}{ Treatments } & \multicolumn{2}{|c|}{$\begin{array}{l}\text { Plant height } \\
\text { (cm) }\end{array}$} & \multicolumn{2}{|c|}{$\begin{array}{c}\text { Branch number } \\
\text { per plant }\end{array}$} & \multicolumn{2}{|c|}{$\begin{array}{l}\text { Stem diameter } \\
\text { (cm) }\end{array}$} & \multicolumn{2}{|c|}{$\begin{array}{l}\text { Stem dry weight } \\
\text { (g) }\end{array}$} \\
\hline $\begin{array}{c}\mathbf{P b} \\
(\mathbf{m g} / \mathbf{l})\end{array}$ & $\begin{array}{c}\text { CA } \\
(\mathrm{mg} / \mathrm{l})\end{array}$ & 2018 & 2019 & 2018 & 2019 & 2018 & 2019 & 2018 & 2019 \\
\hline & 0 & 33.58 & 39.41 & 7.00 & 11.83 & 0.53 & 0.68 & 2.84 & 4.41 \\
\hline \multirow[t]{2}{*}{$\mathbf{0}$} & 250 & 34.91 & 40.08 & 7.16 & 12.33 & 0.54 & 0.71 & 2.97 & 4.87 \\
\hline & 500 & 35.58 & 41.08 & 7.83 & 12.83 & 0.56 & 0.75 & 3.58 & 4.98 \\
\hline \multirow[t]{2}{*}{ Mean (Pb) } & & 34.69 & 40.19 & 7.33 & 12.33 & 0.54 & 0.71 & 3.13 & 4.75 \\
\hline & 0 & 32.58 & 38.41 & 6.66 & 10.66 & 0.49 & 0.66 & 2.54 & 4.06 \\
\hline \multirow[t]{2}{*}{100} & 250 & 33.58 & 38.75 & 6.83 & 10.83 & 0.51 & 0.67 & 2.58 & 4.14 \\
\hline & 500 & 34.25 & 40.08 & 7.00 & 11.66 & 0.52 & 0.71 & 2.72 & 4.51 \\
\hline \multirow[t]{2}{*}{ Mean (Pb) } & & 33.47 & 39.08 & 6.83 & 11.05 & 0.50 & 0.68 & 2.61 & 4.23 \\
\hline & 0 & 31.08 & 36.91 & 6.33 & 9.83 & 0.47 & 0.65 & 2.36 & 3.73 \\
\hline \multirow[t]{2}{*}{200} & 250 & 31.25 & 37.41 & 6.66 & 10.16 & 0.49 & 0.66 & 2.49 & 3.90 \\
\hline & 500 & 32.25 & 38.08 & 7.00 & 10.50 & 0.50 & 0.67 & 2.66 & 4.37 \\
\hline \multirow[t]{2}{*}{ Mean $(\mathrm{Pb})$} & & 31.52 & 37.46 & 6.66 & 10.16 & 0.48 & 0.66 & 2.50 & 4.00 \\
\hline & o & 30.25 & 36.08 & 5.83 & 8.83 & 0.42 & 0.59 & 2.17 & 3.69 \\
\hline \multirow[t]{2}{*}{300} & 250 & 30.41 & 36.50 & 6.16 & 9.66 & 0.44 & 0.60 & 2.53 & 3.79 \\
\hline & 500 & 31.16 & 37.41 & 6.33 & 10.00 & 0.46 & 0.61 & 2.65 & 4.36 \\
\hline \multirow[t]{2}{*}{ Mean $(\mathrm{Pb})$} & & 30.60 & 36.66 & 6.10 & 9.49 & 0.44 & 0.60 & 2.45 & 3.94 \\
\hline & o & 31.87 & 37.70 & 6.45 & 10.28 & 0.47 & 0.64 & 2.47 & 3.97 \\
\hline \multirow[t]{3}{*}{ Mean (CA) } & 250 & 32.53 & 38.18 & 6.70 & 10.74 & 0.49 & 0.66 & 2.64 & 4.17 \\
\hline & 500 & 33.31 & 39.16 & 7.04 & 11.24 & 0.51 & 0.68 & 2.90 & 4.55 \\
\hline & $\mathbf{P b}$ & 0.60 & 0.52 & 0.41 & 1.81 & 0.04 & 0.03 & 0.22 & 0.32 \\
\hline \multicolumn{2}{|c|}{ L.S.D. at $0.05 C A$} & 0.69 & 0.58 & 0.27 & 0.74 & 0.02 & 0.03 & 0.12 & 0.28 \\
\hline & $\mathbf{P b} \times \mathbf{C A}$ & 0.80 & 0.67 & 0.31 & 0.85 & 0.02 & 0.03 & 0.13 & 0.32 \\
\hline
\end{tabular}


in the first and second seasons, respectively, compared with the other concentrations.

Regarding the interaction between the irrigation with lead polluted water and spraying with citric acid on stem parameters of Lantana camara plants, the recorded results for the two seasons are presented in presented in Table (4) showed that significant differences were detected between the values obtained from plants receiving the different treatment combinations. The highest values of plant height (35.58 and $41.08 \mathrm{~cm}$ ), number of branch per plant (7.83 and 12.83), stem diameter $(0.56$ and $0.75 \mathrm{~cm})$ and stem dry weight (3.58 and $4.98 \mathrm{~g}$ ) in the first and second seasons, respectively, were obtained for plants irrigated with tap water and sprayed with citric acid at $500 \mathrm{mg} / \mathrm{l}$. On the other hand, the least values of plant height (30.25 and $36.08 \mathrm{~cm}$ ), number of branch per plant (5.83 and 8.83), stem diameter (0.42 and $0.59 \mathrm{~cm})$ and stem dry weight $(2.17$ and
$3.59 \mathrm{~g}$ ) in the first and second seasons, respectively, were obtained for plants irrigated by the highest lead concentration (300 mg/l) and sprayed with citric acid at 0 $\mathrm{mg} / \mathrm{l}$ treatment. In many cases, spraying the plants with citric acid reduced the adverse effect of lead polluted water.

\section{c. Root parameters:}

Data presented in Table (5) showed that irrigation with lead polluted water decreased root parameters, compared to that of plants irrigated with tap water (control). In both seasons, plants irrigated with tap water had the highest values of root length (16.82 and $20.14 \mathrm{~cm}$ ) and root dry weight (2.25 and $3.62 \mathrm{~g}$ ) in the first and second seasons, respectively. Increasing lead concentration in irrigation water caused a steady reduction in root parameter. These reductions in root parameters were significant as compared to the control even at the highest lead concentration (300 $\mathrm{mg} / \mathrm{l})$, which gave root length (15.00 and $18.29 \mathrm{~cm})$ and root dry

Table 5. Means of root length $(\mathrm{cm})$ and root dry weight $(\mathrm{g})$ of Lantana camara plants as influenced by lead (Pb), citric acid (CA) and their combinations $(\mathrm{Pb} \times \mathrm{CA})$ in the two seasons of 2018 and 2019.

\begin{tabular}{|c|c|c|c|c|c|}
\hline \multicolumn{2}{|c|}{ Treatments } & \multicolumn{2}{|c|}{ Root length $(\mathrm{cm})$} & \multicolumn{2}{|c|}{ Root dry weight (g) } \\
\hline $\begin{array}{c}\mathbf{P b} \\
(\mathbf{m g} / \mathbf{l})\end{array}$ & $\begin{array}{c}\text { CA } \\
\text { (mg/l) }\end{array}$ & 2018 & 2019 & 2018 & 2019 \\
\hline \multirow{3}{*}{$\mathbf{0}$} & $\mathbf{0}$ & 16.47 & 19.80 & 2.07 & 3.44 \\
\hline & 250 & 16.83 & 20.14 & 2.13 & 3.51 \\
\hline & 500 & 17.16 & 20.49 & 2.56 & 3.91 \\
\hline \multirow[t]{2}{*}{ Mean (Pb) } & & 16.82 & 20.14 & 2.25 & 3.62 \\
\hline & $\mathbf{0}$ & 15.96 & 19.27 & 1.85 & 2.89 \\
\hline \multirow[t]{2}{*}{100} & 250 & 16.13 & 19.44 & 1.89 & 2.94 \\
\hline & 500 & 16.82 & 20.14 & 1.98 & 3.19 \\
\hline \multirow[t]{2}{*}{ Mean (Pb) } & & 16.30 & 19.61 & 1.90 & 3.00 \\
\hline & $\mathbf{0}$ & 15.19 & 18.48 & 1.75 & 2.67 \\
\hline \multirow[t]{2}{*}{200} & 250 & 15.66 & 18.97 & 1.84 & 2.78 \\
\hline & 500 & 15.84 & 19.14 & 1.93 & 3.09 \\
\hline \multirow[t]{2}{*}{ Mean (Pb) } & & 15.56 & 18.86 & 1.84 & 2.84 \\
\hline & $\mathbf{0}$ & 14.76 & 18.06 & 1.60 & 2.63 \\
\hline \multirow[t]{2}{*}{300} & 250 & 15.01 & 18.30 & 1.84 & 2.71 \\
\hline & 500 & 15.23 & 18.52 & 1.93 & 3.09 \\
\hline \multirow[t]{2}{*}{ Mean (Pb) } & & 15.00 & 18.29 & 1.79 & 2.81 \\
\hline & $\mathbf{0}$ & 15.59 & 18.90 & 1.81 & 2.90 \\
\hline \multirow[t]{3}{*}{ Mean (CA) } & 250 & 15.90 & 19.21 & 1.92 & 2.98 \\
\hline & 500 & 16.26 & 19.57 & 2.10 & 3.32 \\
\hline & $\mathbf{P b}$ & 0.27 & 0.28 & 0.14 & 0.52 \\
\hline \multirow[t]{2}{*}{ L.S.D. at 0.05} & CA & 0.33 & 0.33 & 0.08 & 0.29 \\
\hline & $\mathbf{P b} \times \mathbf{C A}$ & 0.38 & 0.38 & 0.09 & 0.33 \\
\hline
\end{tabular}


weight (1.79 and $2.81 \mathrm{~g}$ ) in the first and second seasons, respectively.

In contrast to the effect of lead treatments, citric acid treatments improved root parameters of Lantana camara plants, compared to the control. Moreover, plants sprayed with $500 \mathrm{mg} / \mathrm{l}$ citric acid had significantly longer root (16.26 and 19.57 $\mathrm{cm})$ and heavier root dry weight (2.10 and $3.32 \mathrm{~g}$ ) in the first and second seasons, respectively, compared to those of control plants, or plants sprayed with any other citric acid concentration.

Regarding the interaction between the irrigation with lead polluted water and citric acid treatments on root parameters of Lantana camara plants, the results in Table (5) showed significant differences between the values obtained for plants receiving the different treatment combinations. The highest values of root length (17.16 and $20.49 \mathrm{~cm}$ ) and root dry weight (2.56 and
$3.91 \mathrm{~g}$ ) in the first and second seasons, respectively, were obtained for the plants irrigated with tap water and sprayed with citric acid at $500 \mathrm{mg} / \mathrm{l}$. On the other hand, the lowest values of root length (14.76 and $18.06 \mathrm{~cm})$ and root dry weight (1.60 and $2.63 \mathrm{~g}$ ) in the first and second seasons, respectively, were obtained for the plants irrigated with the highest lead concentration (300 mg/l) and sprayed with citric acid at 0 mg/l treatment. It is shown from Table (5) that in many cases, spraying the plants with citric acid reduced the harmful effect of lead polluted water with lead.

\section{d. Flowering parameters:}

Data presented in Table (6) showed that, in both seasons, irrigation with lead polluted water decreased the flowering parameters of Lantana camara plants. Plants irrigated with tap water (control) had the highest mean values of number of flowers per plant (22.94 and 29.94) and flower dry weight (1.91 and

Table 6. Means of flower number per plant and flower dry weight (g) of Lantana camara plants as influenced by lead (Pb), citric acid (CA) and their combinations ( $\mathrm{Pb} \times$ CA) in the two seasons of 2018 and 2019.

\begin{tabular}{|c|c|c|c|c|c|}
\hline \multicolumn{2}{|c|}{ Treatments } & \multicolumn{2}{|c|}{ Flower number per plant } & \multicolumn{2}{|c|}{ Flower dry weight (g) } \\
\hline $\begin{array}{c}\mathrm{Pb} \\
(\mathrm{mg} / \mathrm{l})\end{array}$ & $\underset{(\mathrm{mg} / \mathrm{l})}{\mathrm{CA}}$ & 2018 & 2019 & 2018 & 2019 \\
\hline \multirow{3}{*}{$\mathbf{0}$} & $\mathbf{0}$ & 22.50 & 29.33 & 1.72 & 3.10 \\
\hline & 250 & 23.00 & 30.00 & 1.79 & 3.17 \\
\hline & 500 & 23.33 & 30.50 & 2.23 & 3.57 \\
\hline \multirow[t]{2}{*}{ Mean (Pb) } & & 22.94 & 29.94 & 1.91 & 3.28 \\
\hline & $\mathbf{0}$ & 22.00 & 28.83 & 1.51 & 2.55 \\
\hline \multirow[t]{2}{*}{100} & 250 & 22.16 & 29.00 & 1.56 & 2.60 \\
\hline & 500 & 23.00 & 30.00 & 1.64 & 2.85 \\
\hline \multirow[t]{2}{*}{ Mean $(\mathrm{Pb})$} & & 22.38 & 29.27 & 1.57 & 2.66 \\
\hline & $\mathbf{0}$ & 21.00 & 27.66 & 1.40 & 2.33 \\
\hline \multirow[t]{2}{*}{200} & 250 & 21.66 & 28.33 & 1.51 & 2.46 \\
\hline & 500 & 21.83 & 28.50 & 1.59 & 2.75 \\
\hline \multirow{2}{*}{ Mean (Pb) } & & 21.49 & 28.16 & 1.50 & 2.51 \\
\hline & $\mathbf{0}$ & 20.33 & 27.16 & 1.27 & 2.30 \\
\hline \multirow[t]{2}{*}{300} & 250 & 20.83 & 27.50 & 1.51 & 2.36 \\
\hline & 500 & 21.16 & 27.66 & 1.58 & 2.75 \\
\hline \multirow[t]{2}{*}{ Mean (Pb) } & & 20.77 & 27.44 & 1.45 & 2.47 \\
\hline & $\mathbf{0}$ & 21.45 & 28.24 & 1.47 & 2.57 \\
\hline \multirow[t]{3}{*}{ Mean (CA) } & 250 & 21.91 & 28.70 & 1.59 & 2.64 \\
\hline & 500 & 22.33 & 29.16 & 1.76 & 2.98 \\
\hline & $\mathbf{P b}$ & 0.24 & 0.37 & 0.15 & 0.53 \\
\hline \multirow[t]{2}{*}{ L.S.D. at 0.05} & CA & 0.47 & 0.47 & 0.08 & 0.29 \\
\hline & $\mathbf{P b} \times \mathbf{C A}$ & 0.54 & 0.54 & 0.09 & 0.33 \\
\hline
\end{tabular}


$3.28 \mathrm{~g}$ ) in the first and second seasons, respectively. Increasing lead concentration caused significant reductions in flowering parameters, with the highest lead concentration (300 mg/l) giving significantly the least values of number of flowers per plant (20.77 and 27.44) and flower dry weight (1.45 and $2.47 \mathrm{~g}$ ) in the first and second seasons, respectively, compared with the other concentrations.

Flowering parameters were also significantly affected by spraying the plants with citric acid. In both seasons, gradual increasing of citric acid concentration was increased from $0 \mathrm{mg} / \mathrm{l}$ (control) to $500 \mathrm{mg} / \mathrm{l}$. Accordingly, Table (6) showed that Lantana camara plants sprayed with $500 \mathrm{mg} / \mathrm{l}$ citric acid were significantly increased the values of number of flowers per plant (22.33 and 29.16) and flower dry weight (1.76 and 2.98 g) in the first and second seasons, respectively, compared with the other concentrations.

Regarding the interaction between the irrigation with lead polluted water and citric acid treatments, the recorded results in the two seasons showed that, the highest values were obtained for the plants irrigated with tap water and sprayed with citric acid at 500 $\mathrm{mg} / \mathrm{l}$ with values of number of flowers per plant (23.33 and 30.50) and flower dry weight $(2.23$ and $3.57 \mathrm{~g})$ in the first and second seasons, respectively. On the other hand, the plants with mean values of number of flowers per plant (20.33 and 27.16) and flower dry weight (1.27 and $2.30 \mathrm{~g})$ in the first and second seasons, respectively, were recorded for the plants which were irrigated using the highest lead concentration of (300 $\mathrm{mg} / \mathrm{l}$ ) and sprayed with citric acid at $0 \mathrm{mg} / \mathrm{l}$. It is shown that in many cases, spraying the plants with citric acid reduced the harmful effect of polluted water with lead.

\section{Chemical composition: a. Leaf chemical analysis:}

Data presented in Table (7) showed that the highest values of total chlorophyll were obtained for plants irrigated with tap water
(57.21 and 57.69 SPAD) as well as total carbohydrates (17.72 and 17.88\%) in the first and second seasons, respectively, while the maximum proline content (2.52 and 2.49 $\mathrm{mg} / \mathrm{g}$ ) was obtained in the plants irrigated with lead polluted water at $300 \mathrm{mg} / \mathrm{l}$. Increasing the lead concentration in irrigation water resulted in steady significant reductions in the chlorophyll and carbohydrates content, which reached lowest mean value for chlorophyll (51.81 and 52.51 SPAD) and total carbohydrates (15.87 and $16.12 \%)$ in the first and second seasons, respectively, for plants receiving the highest lead concentration (300 mg/l), while, the least proline content (1.36 and $1.40 \mathrm{mg} / \mathrm{g}$ ) were obtained for the plants irrigated with tap water.

Data in Table (7) showed also that citric acid treatments had possible effect on leaf chlorophyll (55.29 and 55.75 SPAD) and total carbohydrates (17.66 and $17.23 \%$ ) in the first and second seasons, respectively, in plants sprayed with citric acid at $500 \mathrm{mg} / \mathrm{l}$, while, the higher proline contents (2.03 and $2.06 \mathrm{mg} / \mathrm{g}$ ) were obtained in plants sprayed without citric acid (tap water).

Regarding to the interaction between the irrigation with lead polluted water and citric acid treatments, the highest total chlorophyll contents (58.87 and 59.25 SPAD) and total carbohydrates (18.29 and $18.42 \%$ ) in the first and second seasons, respectively, were found in leaves of plants irrigated with tap water and sprayed with citric acid at 250 $\mathrm{mg} / \mathrm{l}$, while, the higher proline contents (2.53 and $2.51 \mathrm{mg} / \mathrm{g}$ ) were resulted for the plants irrigated by the highest lead concentration (300 mg/l) without citric acid treatment.

\section{b. Lead content in leaves, stem and root (mg/l):}

Data presented in Table (8) showed that, the lead content $(\mathrm{mg} / \mathrm{l})$ in the dried plant parts of Lantana camara plants was increased with increasing the lead concentration in the irrigation water. Generally, the lowest mean lead content of leaves $(0.182$ and $0.343 \mathrm{mg} / \mathrm{l})$, lead content 
Table 7. Means of some chlorophyll content (SPAD), carbohydrates content (\%) and proline content (mg/g D.W) of Lantana camara plants as influenced by lead $(\mathrm{Pb})$, citric acid $(\mathrm{CA})$ and their combinations $(\mathrm{Pb} \times \mathrm{CA})$ in the two seasons of 2018 and 2019.

\begin{tabular}{|c|c|c|c|c|c|c|c|}
\hline \multicolumn{2}{|c|}{ Treatments } & \multicolumn{2}{|c|}{$\begin{array}{c}\text { Chlorophyll content } \\
\text { (SPAD) }\end{array}$} & \multicolumn{2}{|c|}{$\begin{array}{c}\text { Carbohydrate content } \\
\text { (\%) }\end{array}$} & \multicolumn{2}{|c|}{$\begin{array}{l}\text { Proline content } \\
\text { (mg/g d.w.) }\end{array}$} \\
\hline $\begin{array}{c}\mathbf{P b} \\
(\mathbf{m g} / \mathbf{l})\end{array}$ & $\begin{array}{c}\text { CA } \\
(\mathrm{mg} / \mathrm{l})\end{array}$ & 2018 & 2019 & 2018 & 2019 & 2018 & 2019 \\
\hline & $\mathbf{0}$ & 55.55 & 56.26 & 17.16 & 17.39 & 1.42 & 1.45 \\
\hline \multirow[t]{2}{*}{$\mathbf{0}$} & 250 & 58.87 & 59.25 & 18.29 & 18.42 & 1.39 & 1.42 \\
\hline & 500 & 57.22 & 57.58 & 17.72 & 17.85 & 1.28 & 1.33 \\
\hline \multirow[t]{2}{*}{ Mean (Pb) } & & 57.21 & 57.69 & 17.72 & 17.88 & 1.36 & 1.40 \\
\hline & 0 & 51.71 & 52.09 & 15.85 & 15.97 & 1.87 & 1.93 \\
\hline \multirow[t]{2}{*}{100} & 250 & 58.45 & 58.83 & 18.14 & 18.27 & 1.84 & 1.86 \\
\hline & 500 & 56.67 & 57.42 & 17.54 & 17.80 & 1.83 & 1.85 \\
\hline \multirow[t]{2}{*}{ Mean (Pb) } & & 55.61 & 56.11 & 17.17 & 17.34 & 1.84 & 1.88 \\
\hline & $\mathbf{0}$ & 50.11 & 51.13 & 15.30 & 15.65 & 2.30 & 2.35 \\
\hline \multirow[t]{2}{*}{200} & 250 & 56.04 & 56.43 & 17.32 & 17.46 & 2.27 & 2.31 \\
\hline & 500 & 55.12 & 55.49 & 17.01 & 17.13 & 2.24 & 2.30 \\
\hline \multirow[t]{2}{*}{ Mean (Pb) } & & 53.75 & 54.35 & 16.54 & 16.74 & 2.27 & 2.32 \\
\hline & $\mathbf{0}$ & 49.07 & 50.11 & 14.95 & 15.30 & 2.53 & 2.51 \\
\hline \multirow{2}{*}{300} & 250 & 54.20 & 54.91 & 16.69 & 16.94 & 2.52 & 2.49 \\
\hline & 500 & 52.17 & 52.53 & 15.99 & 16.14 & 2.51 & 2.48 \\
\hline \multirow[t]{2}{*}{ Mean (Pb) } & & 51.81 & 52.51 & 15.87 & 16.12 & 2.52 & 2.49 \\
\hline & 0 & 51.61 & 52.39 & 15.81 & 16.07 & 2.03 & 2.06 \\
\hline \multirow[t]{3}{*}{ Mean (CA) } & 250 & 56.89 & 57.35 & 17.61 & 17.77 & 2.00 & 2.02 \\
\hline & 500 & 55.29 & 55.75 & 17.06 & 17.23 & 1.96 & 1.99 \\
\hline & $\mathbf{P b}$ & 0.52 & 0.48 & 0.17 & 0.16 & 0.05 & 0.04 \\
\hline \multirow[t]{2}{*}{ L.S.D. at 0.05} & CA & 0.38 & 0.38 & 0.13 & 0.13 & 0.01 & 0.01 \\
\hline & $\mathrm{Pb} \times \mathrm{CA}$ & 0.44 & 0.43 & 0.15 & 0.15 & 0.02 & 0.01 \\
\hline
\end{tabular}

of stem $(0.222$ and $0.240 \mathrm{mg} / \mathrm{l})$ and lead content of root $(0.136$ and $0.123 \mathrm{mg} / \mathrm{l})$ in the first and second seasons, respectively, were recorded in leaves of plants irrigated with tap water, whereas the highest mean values of lead content of the leaves $(0.995$ and 1.034 $\mathrm{mg} / \mathrm{l})$, stem $(0.627$ and $0.697 \mathrm{mg} / \mathrm{l})$ and root (0.502 and $0.541 \mathrm{mg} / \mathrm{l}$ ) in the first and second seasons, respectively, were registered for plants irrigated with water containing the highest lead concentration (300 mg/l).

Concerning the effect of citric acid treatments on the lead content in plant parts, citric acid treatment of $500 \mathrm{mg} / \mathrm{l}$ caused a significant decrease in the mean values of lead content in the leaves $(0.621$ and 0.712 $\mathrm{mg} / \mathrm{l})$, stem $(0.448$ and $0.488 \mathrm{mg} / \mathrm{l})$ and root $(0.349$ and $0.374 \mathrm{mg} / \mathrm{l})$ in the first and second seasons, respectively, compared to those of control plants had the highest lead content in the leaves $(0.676$ and $0.769 \mathrm{mg} / \mathrm{l})$, stem $(0.468$ and $0.511 \mathrm{mg} / \mathrm{l})$ and root $(0.365$ and $0.386 \mathrm{mg} / \mathrm{l})$ in the first and second seasons, respectively.

Concerning the interaction between irrigation using lead polluted water with lead and citric acid treatments on the lead content in plant parts, the lowest mean values of lead content in the leaves $(0.141$ and $0.306 \mathrm{mg} / \mathrm{l})$, stem $(0.219$ and $0.226 \mathrm{mg} / \mathrm{l})$ and root $(0.131$ and $0.119 \mathrm{mg} / \mathrm{l}$ ) in the first and second seasons, respectively, were recorded for plants irrigated with tap water and sprayed with citric acid at $500 \mathrm{mg} / \mathrm{l}$. On the other hand, the highest lead content was obtained in the plant parts irrigated with lead polluted water at $300 \mathrm{mg} / \mathrm{l}$ and void of citric acid giving lead content in the leaves (1.003 and $1.049 \mathrm{mg} / \mathrm{l})$, stem (0.641 and $0.710 \mathrm{mg} / \mathrm{l})$ and root (0.513 and $0.542 \mathrm{mg} / \mathrm{l})$. 
Table 8. Means of lead content of Lantana camara plants as influenced by lead (Pb), citric acid (CA) and their combinations $(\mathrm{Pb} \times \mathrm{CA})$ in the two seasons of 2018 and 2019.

\begin{tabular}{|c|c|c|c|c|c|c|c|}
\hline \multicolumn{2}{|c|}{ Treatments } & \multicolumn{2}{|c|}{$\begin{array}{l}\text { Lead content in leaves } \\
(\mathrm{mg} / \mathrm{kg})\end{array}$} & \multicolumn{2}{|c|}{$\begin{array}{l}\text { Lead content in stem } \\
(\mathrm{mg} / \mathrm{kg})\end{array}$} & \multicolumn{2}{|c|}{$\begin{array}{l}\text { Lead content in roots } \\
(\mathrm{mg} / \mathrm{kg})\end{array}$} \\
\hline $\begin{array}{c}\mathbf{P b} \\
(\mathbf{m g} / \mathbf{l})\end{array}$ & $\begin{array}{c}\text { CA } \\
(\mathrm{mg} / \mathrm{l})\end{array}$ & 2018 & 2019 & 2018 & 2019 & 2018 & 2019 \\
\hline \multirow{3}{*}{$\mathbf{0}$} & 0 & 0.234 & 0.391 & 0.225 & 0.248 & 0.141 & 0.128 \\
\hline & 250 & 0.172 & 0.332 & 0.224 & 0.246 & 0.137 & 0.124 \\
\hline & 500 & 0.141 & 0.306 & 0.219 & 0.226 & 0.131 & 0.119 \\
\hline \multirow[t]{2}{*}{ Mean (Pb) } & & 0.182 & 0.343 & 0.222 & 0.240 & 0.136 & 0.123 \\
\hline & 0 & 0.556 & 0.713 & 0.427 & 0.496 & 0.347 & 0.401 \\
\hline \multirow[t]{2}{*}{100} & 250 & 0.538 & 0.695 & 0.418 & 0.488 & 0.341 & 0.395 \\
\hline & 500 & 0.494 & 0.652 & 0.398 & 0.468 & 0.326 & 0.380 \\
\hline \multirow[t]{2}{*}{ Mean (Pb) } & & 0.529 & 0.686 & 0.414 & 0.484 & 0.338 & 0.392 \\
\hline & 0 & 0.912 & 0.925 & 0.579 & 0.591 & 0.461 & 0.474 \\
\hline \multirow[t]{2}{*}{200} & 250 & 0.879 & 0.893 & 0.564 & 0.576 & 0.451 & 0.463 \\
\hline & 500 & 0.859 & 0.883 & 0.555 & 0.572 & 0.444 & 0.459 \\
\hline \multirow[t]{2}{*}{ Mean (Pb) } & & 0.883 & 0.900 & 0.566 & 0.579 & 0.452 & 0.465 \\
\hline & 0 & 1.003 & 1.049 & 0.641 & 0.710 & 0.513 & 0.542 \\
\hline \multirow{2}{*}{300} & 250 & 0.993 & 1.047 & 0.620 & 0.693 & 0.499 & 0.541 \\
\hline & 500 & 0.990 & 1.008 & 0.620 & 0.688 & 0.495 & 0.540 \\
\hline \multirow[t]{2}{*}{ Mean (Pb) } & & 0.995 & 1.034 & 0.627 & 0.697 & 0.502 & 0.541 \\
\hline & $\mathbf{0}$ & 0.676 & 0.769 & 0.468 & 0.511 & 0.365 & 0.386 \\
\hline \multirow[t]{3}{*}{ Mean (CA) } & 250 & 0.645 & 0.741 & 0.456 & 0.500 & 0.357 & 0.380 \\
\hline & 500 & 0.621 & 0.712 & 0.448 & 0.488 & 0.349 & 0.374 \\
\hline & $\mathbf{P b}$ & 0.062 & 0.056 & 0.029 & 0.030 & 0.029 & 0.023 \\
\hline \multirow[t]{2}{*}{ L.S.D. at 0.05} & CA & 0.057 & 0.042 & 0.028 & 0.019 & 0.022 & 0.019 \\
\hline & $\mathbf{P b} \times \mathbf{C A}$ & 0.065 & 0.048 & 0.031 & 0.022 & 0.024 & 0.022 \\
\hline
\end{tabular}

c. Transfer factor (TF) of heavy metals:

1. Lead content in soil samples $(\mathrm{mg} / \mathrm{kg})$ :

Data presented in Table (9) showed that the lowest average value of lead content was in untreated soil, while the highest average was observed in soil after the treatment by $300 \mathrm{mg} / \mathrm{l}$ lead and $0 \mathrm{mg} / \mathrm{l}$ citric acid.

\section{Transfer factor to leaves, stem and root:}

Data presented in Table (10), showed that the transfer factor (TF) in the dried plant parts of Lantana camara plants was steadily increased with increasing lead concentration in irrigation water. Accordingly, the highest lead values in leaves (1.509 and $1.396 \mathrm{mg} / \mathrm{l})$, stem $(0.950$ and $0.940 \mathrm{mg} / \mathrm{l})$ and root $(0.761$ and $0.730 \mathrm{mg} / \mathrm{l})$ were recorded plants irrigated with water containing lead concentration of $300 \mathrm{mg} / \mathrm{l}$, whereas the lowest values were for leaves (0.812 and $1.346 \mathrm{mg} / \mathrm{l})$, stem $(0.974$ and $0.935 \mathrm{mg} / \mathrm{l})$ and root $(0.597$ and $0.481 \mathrm{mg} / \mathrm{l})$ for plants irrigated with tap water (control).

Data showed also that the transfer factor (TF) in the dried plant parts was steadily reduced with increasing citric acid concentration. Accordingly, the highest lead values in the leaves (1.559 and $1.448 \mathrm{mg} / \mathrm{l})$, stem $(0.996$ and $0.980 \mathrm{mg} / \mathrm{l})$ and root $(0.797$ and $0.748 \mathrm{mg} / \mathrm{l}$ ) were obtained in the leaves of control plants, whereas plants sprayed with the highest citric acid concentration (500 mg/l) had the lowest lead values in the leaves (1.468 and $1.329 \mathrm{mg} / \mathrm{l})$, stem (0.919 and $0.907 \mathrm{mg} / \mathrm{l})$ and root $(0.734$ and 0.712 $\mathrm{mg} / \mathrm{l}$ ) of the two seasons, respectively.

\section{DISCUSSION}

This study revealed that at high heavy metal concentrations, the biomass was significantly reduced. The leaves growth was more sensitive than other parts, as leaves rapidly absorbed water and had higher accumulations of heavy metals. The results 
Table 9. Average values of lead content in soil samples as influenced by lead concentrations in irrigation water and foliar application of citric acid on Lantana camara in the two seasons of 2018 and 2019.

\begin{tabular}{|c|c|c|c|c|c|}
\hline \multicolumn{2}{|c|}{ Treatments } & \multicolumn{4}{|c|}{ Lead content in soil (mg/kg) } \\
\hline \multirow{2}{*}{$\begin{array}{l}\text { Lead } \\
\text { (mg/l) }\end{array}$} & \multirow{2}{*}{$\begin{array}{c}\text { Citric acid } \\
(\mathrm{mg} / \mathrm{l})\end{array}$} & \multicolumn{2}{|c|}{2018} & \multicolumn{2}{|c|}{2019} \\
\hline & & Before & After & Before & After \\
\hline & 0 & 0.085 & 0.204 & 0.096 & 0.230 \\
\hline \multirow[t]{3}{*}{$\mathbf{0}$} & 250 & 0.098 & 0.235 & 0.110 & 0.264 \\
\hline & 500 & 0.105 & 0.252 & 0.118 & 0.283 \\
\hline & 0 & 0.169 & 0.405 & 0.190 & 0.456 \\
\hline \multirow[t]{3}{*}{100} & 250 & 0.178 & 0.427 & 0.201 & 0.482 \\
\hline & 500 & 0.186 & 0.446 & 0.209 & 0.501 \\
\hline & 0 & 0.248 & 0.595 & 0.279 & 0.669 \\
\hline \multirow[t]{3}{*}{200} & 250 & 0.254 & 0.609 & 0.286 & 0.686 \\
\hline & 500 & 0.265 & 0.636 & 0.298 & 0.715 \\
\hline & 0 & 0.268 & 0.643 & 0.302 & 0.724 \\
\hline \multirow[t]{2}{*}{300} & 250 & 0.275 & 0.661 & 0.309 & 0.741 \\
\hline & 500 & 0.281 & 0.674 & 0.316 & 0.758 \\
\hline
\end{tabular}

Table 10. Means of transfer factor to leaves, stem and roots of Lantana camara plants as influenced by lead $(\mathrm{Pb})$, citric acid $(\mathrm{CA})$ and their combinations $(\mathrm{Pb} \times \mathrm{CA})$ in the two seasons of 2018 and 2019.

\begin{tabular}{|c|c|c|c|c|c|c|c|}
\hline \multicolumn{2}{|c|}{ Treatments } & \multicolumn{2}{|c|}{$\begin{array}{l}\text { Transfer factor to } \\
\text { leaves (TFL) }\end{array}$} & \multicolumn{2}{|c|}{$\begin{array}{l}\text { Transfer factor to } \\
\text { stem (TFS) }\end{array}$} & \multicolumn{2}{|c|}{$\begin{array}{l}\text { Transfer factor to } \\
\text { roots (TFR) }\end{array}$} \\
\hline $\begin{array}{c}\mathbf{P b} \\
(\mathbf{m g} / \mathbf{l})\end{array}$ & $\begin{array}{c}\mathrm{CA} \\
(\mathrm{mg} / \mathrm{l})\end{array}$ & 2018 & 2019 & 2018 & 2019 & 2018 & 2019 \\
\hline \multirow{3}{*}{ 0 } & 0 & 1.147 & 1.700 & 1.102 & 1.078 & 0.691 & 0.556 \\
\hline & 250 & 0.731 & 1.257 & 0.953 & 0.931 & 0.582 & 0.469 \\
\hline & 500 & 0.559 & 1.081 & 0.869 & 0.798 & 0.519 & 0.420 \\
\hline \multirow[t]{2}{*}{ Mean $(\mathrm{Pb})$} & & 0.812 & 1.346 & 0.974 & 0.935 & 0.597 & 0.481 \\
\hline & 0 & 1.372 & 1.563 & 1.054 & 1.087 & 0.856 & 0.879 \\
\hline \multirow[t]{2}{*}{100} & 250 & 1.259 & 1.441 & 0.978 & 1.012 & 0.798 & 0.819 \\
\hline & 500 & 1.107 & 1.301 & 0.892 & 0.934 & 0.730 & 0.758 \\
\hline \multirow[t]{2}{*}{ Mean (Pb) } & & 1.246 & 1.435 & 0.974 & 1.011 & 0.794 & 0.818 \\
\hline & 0 & 1.532 & 1.382 & 0.973 & 0.883 & 0.774 & 0.708 \\
\hline \multirow[t]{2}{*}{200} & 250 & 1.443 & 1.301 & 0.926 & 0.839 & 0.740 & 0.674 \\
\hline & 500 & 1.350 & 1.234 & 0.872 & 0.800 & 0.698 & 0.641 \\
\hline \multirow[t]{2}{*}{ Mean (Pb) } & & 1.441 & 1.305 & 0.923 & 0.840 & 0.737 & 0.674 \\
\hline & 0 & 1.559 & 1.448 & 0.996 & 0.980 & 0.797 & 0.748 \\
\hline \multirow[t]{2}{*}{300} & 250 & 1.502 & 1.412 & 0.937 & 0.935 & 0.754 & 0.730 \\
\hline & 500 & 1.468 & 1.329 & 0.919 & 0.907 & 0.734 & 0.712 \\
\hline \multirow[t]{2}{*}{ Mean (Pb) } & & 1.509 & 1.396 & 0.950 & 0.940 & 0.761 & 0.730 \\
\hline & 0 & 1.402 & 1.523 & 1.031 & 1.007 & 0.779 & 0.722 \\
\hline \multirow{2}{*}{ Mean (CA) } & 250 & 1.233 & 1.352 & 0.948 & 0.929 & 0.718 & 0.673 \\
\hline & 500 & 1.121 & 1.236 & 0.888 & 0.859 & 0.670 & 0.632 \\
\hline
\end{tabular}

presented in this study were in agreement with earlier reports on other plants, such as aquatic plant Wolffia arrhiza (Piotrowska et al., 2010), barley Hordeum vulgare (Tiryakioglu et al., 2006) and Typha angustifolia (Bah et al., 2011). Other studies with woody plants reported a higher inhibition of root elongation (Dominguez et al., 2009). In particular, Jatropha plants could bioaccumulate and bioconcentrate toxic heavy metals from an aqueous solution (Mohammad et al., 2010) and could be used as phytoremediation candidates in some 
countries (Juwarkar et al., 2008; Kumar et al., 2008 and Jamil et al., 2009).

Plants can tolerate lead either by external exclusion or internal tolerance. By the external exclusion, lead ions are excluded from entering the plant cells and thus lead cannot accumulates in the organelles and excess lead ions are removed out of the plant cell (Sharma and Dubey 2005). The internal tolerance of lead is mainly due to the synthesis of organic lead compounds (cysteine, glutathione, phytochelatin, etc) and eventually the lead ions are transformed in the cell into chemically bound structures with lower toxicity, alleviating the $\mathrm{Pb}$ toxic effect on the plant tissues (Pourrut et al., 2011). Lead can damage the ultrastructures of the organs, tissues, chloroplast, mitochondria, nucleus, cell wall, and cell membrane in the plants. This damage can cause a loss of organelle function, and can eventually affect the normal physiological functions that include photosynthesis, respiration, protein synthesis, cell division within the plant species (Salazar and Pignata, 2014).

Concerning treatments and the control sample, at a preliminary stage, one should note that the transfer factor of most treatments is lower than one for lead; which means that the physiological need of the plant for these elements is rather limited.

Trace elements translocation from roots to shoots via a number of physiological processes, including metal unloading into root xylem cells, long-distance carrying from the xylem to the shoots and metal reabsorption, by leaf mesophyll cells, from the xylem stream. Once the trace metals have been unloaded into the xylem vessels, the metals are carried to the shoots by the transpiration stream (Blaylock and Huang, 2000).

For the effect of citric acid it is observed that there is a significant increase in all vegetative parameters, chlorophyll content, carbohydrate percentage, significant decrease in lead content in the leaves and roots and decrease in lead content. This may be due to that application of citric acid with any of the concentrations of lead led to a statistically decrease in the uptake of lead. This decrease in uptake of lead in the presence of citric acid resulted in the formation of citric acid-lead complexes that inhibited the uptake (Chen et al., 2003). The decrease in lead uptake helped to overcome the negative effects of lead on the previous studied parameters. These results are in agreement with those mentioned by (Talebi et al., 2014) on Gazania plants and (Jaafari and Hadavi, 2012) on Ocimum basilicum L. and (El-Shanhorey et al., 2019) on Senecio cineraria.

\section{CONCLUSION}

Phytoremediation is a new cleanup concept that involves the use of non-edible plants to clean or stabilize contaminated environments. Phytoremediation of metals is the most effective plant-based method to remove pollutants from contaminated areas. This green technology can be applied to remediate the polluted soils without creating any destructive effect of soil structure. Some specific plants, such as woody species, have been proven to have noticeable potential to absorb toxic heavy metals.

We conclude that we can use Lantana camara plants as lead phytoremediation plant without spraying with citric acid and if we want to use Lantana camara as an ornamental plant and the water irrigation is contaminated with lead, we can spray the plants with citric acid to overcome the negative effect of lead.

\section{REFERENCES}

Bah, A.M.; Dai, H.; Zhao, J.; Sun, H.; Cao, F.; Zhang, G. and Wu, F. (2011). Effects of lead, chromium and lead on growth, metal uptake and antioxidative capacity in Typha angustifolia. Biol. Trace Elem. Res., 142: 77-92.

Bates, L.S.; Waldern, R.P. and Teare, L. D. (1973). Rapid determination of free 
proline under water stress studies. Plant and Soil, 39:205-207.

Blaylock, M.J. and Huang, J.W. (2000). Phytoextraction of metals. Phytoremediation of toxic metals: using plants to clean up the environment. Eds., Raskin, I. and B.D. Ensley. John Wiley and Sons, Inc, Toronto, 303 p.

Boussama, N.; Ouariti, A.; Suzuki, A. and Ghorbal, M.H. (1999). Cd-stress on nitrogen assimilation. J. Plant Physiol. 155:310-317.

Chen, Y.; Shen, Z. and Li, X. (2004). The use of vetiver grass (Vetiveria zizanioides) in the phytoremediation of soils contaminated with heavy metals. Applied Geochemistry, 19: 1553-1565.

Chen, Y.X.; Lin, Q.; Luo, Y.M.; He, Y.F.; Zhen, S.J.; Yu, Y.L.; Tian, G.M. and Wong, M.H. (2003). The role of citric acid on the phytoremediation of heavy metal contaminated soil. Chemosphere, 50:507-811.

Choruk, K.; Kurukote, J.; Supprung, P. and Vetayasuporn, S. (2006). Perennial plants in the phytoremediation of leadcontaminated soils. Biotechnology, 5(1):1-4.

Cuypers, A.; Vangronsveld, J. and Clijsters, H. (1999). The chemical behavior of heavy metals plays a prominent role in the induction of oxidative stress. Free Radical Res. 31:539-543.

Da Silva, J.A.T. (2003). The cut flower: postharvest considerations, J. Biol. Sci., 3(4):406-442.

Dominguez, M.T.; Madrid, F.; Maranon, T. and Murillo, J.M. (2009). Lead availability in soil and retention in oak roots: potential for phytostabilization. Chemosphere, 76:480-486.

Dubios, M.; Gilles, K.; Hamlton, J.; Rebers, P. and Smith, F. (1956). Colourimetric method for determination of sugars and related substances. Analytical Chemistry, 28(3):350-356.
El-Shanhorey, N.A.; Adam, A.I. and ELTony, F.Z. (2019). The use of Senecio cineraria plants sprayed with citric acid for Lead pollution phytoremediation. Bull. Fac. Agric. Cairo Univ. 70 (1):1929.

Huynh, T.M.D. (2009). Effects of Heavy Metals on the Interactions Between Plant/Earthworm/Telluric Microflora. Ph.D. Thesis, University Paris-Est, Paris.

Jaafari, N. and Hadavi, E. (2012). Growth and essential oil yield of Basil (Ocimum basilicum L.) as affected by foliar spray of citric acid and salicylic acid. Zeitschrift fur Arznei- und Gewurzpflanzen, 17(2):80-83.

Jackson, N.L. (1958). Soil Chemical Analysis. Constable. Ltd. Co., London, $498 \mathrm{p}$.

Jamil, S.; Abhilash, P.C.; Singh, N. and Sharma, P.N. (2009). Jatropha curcas: a potential crop for phytoremediation of coal fly ash. J. Hazard. Mater., 172:269275.

Juwarkar, A.A.; Yadav, S.K.; Kumar, P. and Singh, S.K. (2008). Effect of biosludge and biofertilizer amendment on growth of Jatropha curcas in heavy metal contaminated soils. Environ. Monit. Assess., 145:7-15.

Koller, H.R. (1972). Leaf area, leaf weight relationship in the soybean canopy. Crop Sci., 12:180-183.

Kumar, G.P.; Yadav, S.K.; Thawale, P.R.; Singh, S.K. and Juwarkar, A.A. (2008). Growth of Jatropha curcas on heavy metal contaminated soil amended with industrial wastes and Azotobacter. A greenhouse study. Bioresour. Technol., 99:2078-2082.

Kurepa, J.; Van Montagu, M. and Inze, D. (1997). Expression of sodCp and sodB genes in Nicotiana tabacum: Effects of light and copper excess. J. Exp. Bot., 48:2007-2014. 
Lindsay, W.L. and Norvell, W.A. (1978). Development of a DTPA soil test for zinc, iron, manganese and copper. Soil Sci. Soc. Am. J., 42:421-428.

Mahler, R.J.; Bingham, F.T. and Chang, A.C. (1981). Effect of heavy metal pollution on plants. Applied Science, 1:72-109.

Malecka, A.; Jarmuszkiewicz, V., Tomaszewska, B. (2001). Antioxidative defense to lead stress in subcellular compartments of pea root cells. Acta Biochem., 3:687-698.

Mohammad, M.; Maitra, S.; Ahmad, N.; Bustam, A.; Sen, T.K. and Dutta, B.K. (2010). Metal ion removal from aqueous solution using physic seed hull. J. Hazard. Mater., 179: 363-372.

Piotrowska, A.; Bajguz, A.; GodlewskaZylkiewicz, B. and Zambrzycka, E. (2010). Changes in growth, biochemical components, and antioxidant activity in aquatic plant Wolffia arrhiza (Lemnaceae) exposed to cadmium and lead. Arch. Environ. Contam. Toxicol., 58:594-604.

Piper, O.S. (1947). Soil and Plant Analysis. Adelaite University, Adelaide, Australia, pp. 258-275.

Pourrut, B.; Shahid, M.; Dumat, C.; Winterton, P. and Pinelli, E. (2011). Lead uptake, toxicity, and detoxification in plants. Rev. Environ. Contam., 213:113-136.

Prasad, K.V.S.K.; Paradha Saradhi, P. and Sharmila, P. (1999). Concerted action of antioxidant enzymes and curtailed growth under zinc toxicity in Brassica juncea. Environ. Exp. Botany, 42:1-10.

Rauser, W.R. (1995). Phytochelatins and related peptides, structure, biosynthesis and function. Plant Physiol., 109:11411149 .

Salazar, M.J. and Pignata, M.L. (2014). Lead accumulation in plants grown in polluted soils. Screening of native species for phytoremediation. J. Geochem. Explor., 137:29-36.

SAS Institute (2002). SAS User Guide and Program 20 Version 9.0.38. Cary, North Carolina, USA.

Sharma, B.D.; Mukhopadhyay, S.S. and Katyal, J.C. (2006). Distribution of total and DTPA- extractable zinc, copper, manganese and iron in vertisols of India. Commun Soil Sci Plant Anal., 37:653672.

Sharma, P. and Dubey, R.S. (2005). Lead toxicity in plants. Brazilian J. Plant Physiol., 17:35-52.

Snedecor, G.W. and Cochran, W. (1989). Statistical Methods, $8^{\text {th }}$ ed. Edition, Iowa State University Press. Ames. Iowa, USA, $491 \mathrm{p}$.

Taize, L. and Zeiger, E. (2002). Plant Physiology, $\quad 3^{\text {rd }}$ Edition. Sinauer Associates Inc., Sunderland, MA, USA. $291 \mathrm{p}$.

Talebi, M.; Hadavi, E. and Jaafari, N. (2014). Foliar sprays of citric acid and malic acid modify growth, flowering, and root to shoot ratio of gazania (Gazaniarigens L.): A comparative analysis by ANOVA and structural equations modeling. Adv. Agric. Article ID, 147278:1-6.

Unhalekhana, U. and Kositanont, C. (2008). Distribution of lead in soil around zinc mining area. Thai Journal of Toxicology, 23:170-174.

Wills, R.; Lee, T.; Graham, D.; McGlasson, W. and Hall, E. (1981). Post-harvest: An Introduction to the Physiology and Handling of Fruit and Vegetables. Kensington, NSW, New South Wales Univ. Press, United Kingdom, 161 p.

Wua, G.; Kanga, H.; Zhangc, X.; Shaob, H.; Chuc, L. and Ruand, C. (2010). A critical review on the bio-removal of hazardous heavy metals from contaminated soils: Issues, progress, eco- 
environmental concerns and opportunities. J. Haz. Mat., 174:1-8.

chlorophyll in intact leaves. Hort. Sci., 21(6):1449-1450.

Yadava, U. (1986). A rapid and nondestructive method to determine

$$
\begin{aligned}
& \text { إستجابة نباتات اللانتانا للرش بحمض الستريك لتقليل الأثر الضار }
\end{aligned}
$$

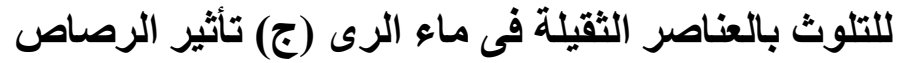



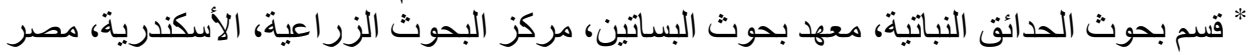

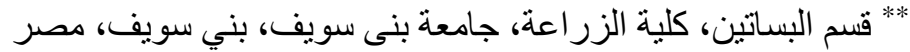

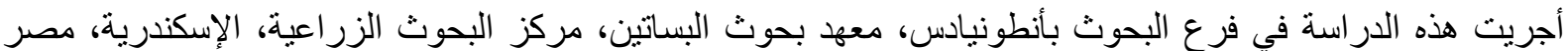

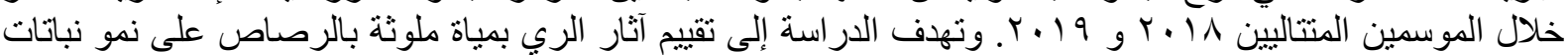

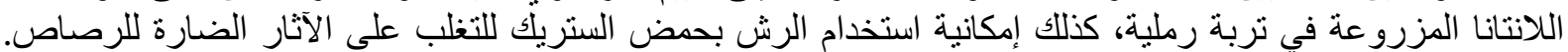

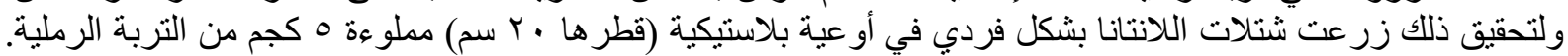

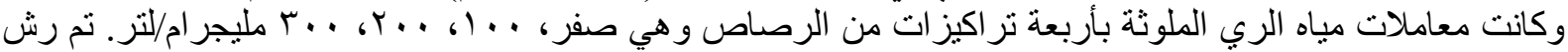

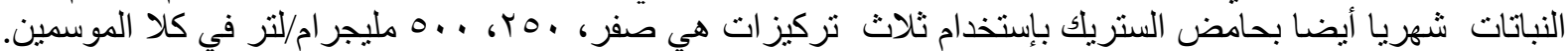

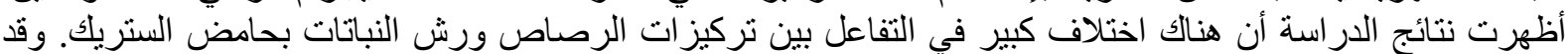

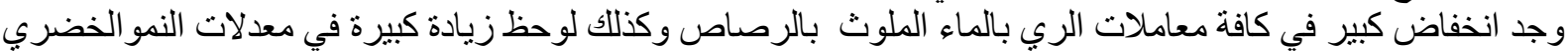

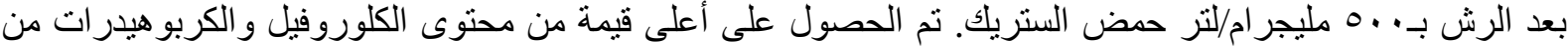

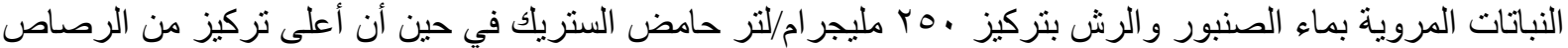

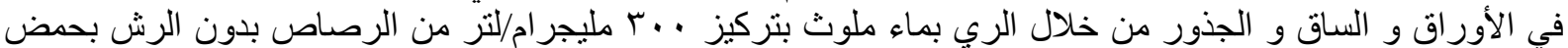
الستريك. 